\title{
ARTICLE \\ Municipal Solid Waste in Turkey and Its Relationship with the Population
}

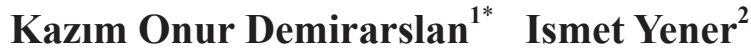 \\ 1.Department of Environmental Engineering, Artvin Coruh University, Artvin, 08000, Turkey \\ 2.Department of Forestry, Artvin Coruh University, Artvin, 08000, Turkey
}

\section{ARTICLE INFO}

Article history

Received: 8 February 2021

Accepted: 25 March 2021

Published Online: 30 March 2021

Keywords:

Municipal solid waste

Disposal methods

Developing countries

Turkey

\begin{abstract}
The population of Turkey has increased rapidly in parallel with the rise in technology and industrialization. The increasing population of the country has triggered urbanization, and environmental problems have drawn attention. One of the issues resulting from urbanization is municipal solid waste (MSW). Every object we use in our daily life is transformed into solid waste when its economic life has ended. The processes from the storage of these wastes to their disposal, often referred to as MSW management, come under the municipalities' authority and responsibility. MSW must be processed with the most negligible environmental impact. This study aimed to investigate MSW management systems in Turkey, including the quantity, composition, and disposal methods of MSW generated and populations served by MSW, MSW per capita per day. Results from the study showed that the mean MSW generated in Turkey was $26.74 \mathrm{Mton} / \mathrm{yr}$ and increased in the following order by region; Eastern Anatolia $<$ South East Anatolia $<$ Black Sea $<$ Mediterranean $<$ Aegean $<$ Central Anatolia $<$ Marmara. This order/ranking was in line with the regions' population. The population explained 84 to $95 \%$ of the variation in MSW. Results from the study could be used in MSW management.
\end{abstract}

Africa, and sub-Saharan Africa are responsible for $15 \%$ of the total production.

Similarly, when looking at MSW per capita, the lowest and highest production belongs to sub-Saharan Africa $(0.46 \mathrm{~kg} /$ day $)$ and North America $(2.21 \mathrm{~kg} /$ day $)$, respectively ${ }^{[4]}$. As one of the 20 most populated countries in the world, Turkey's population growth rate $(1.9 \%)$ is higher than that of most developing countries and the world average $(1.7 \%)^{[5]}$. The amount and components of MSW are strongly linked to changes in people's consumption behavior and rapidly developing technology. MSW comprehends solid wastes from dwellings, businesses, organizations, street garbage, constructions, and wastewater

*Corresponding Author:

Kazım Onur Demirarslan,

Department of Environmental Engineering, Artvin Coruh University, Artvin, 08000, Turkey;

Email: onurdemirarslan@artvin.edu.tr 
treatment facilities. MSW requires special attention due to its diversity/complexity and increasing volumes. The quantity and characteristics of such wastes vary between countries, regions, and even families within the same city.

These characteristics of solid waste materials can be affected by education, job opportunities, family structure, the income level of people, and their consumption habits $[6,7,8,9]$. Industrial and urban MSW can cause severe problems for the environment and human health. Underground and surface water and soil contamination, unwanted odors, insects, air pollution, global warming, and even some explosion events can be cited as examples of these problems. For this reason, MSW management is an issue that concerns all states globally ${ }^{[10,11]}$. Provision of aesthetic and hygienic competence with MSW management is generally the local governments' responsibility, namely provincial, district, and town municipalities ${ }^{[12]}$. Although waste management systems are parallel to relevant technological developments, they are still a fundamental problem for many countries. They are pretty complicated and costly and need to be well organized ${ }^{[13,14]}$.

Global MSW production was calculated as 1.3 billion tons in 2010, and it is estimated to reach 2.2 billion tons in 2025 and 4.2 billion tons in 2050. According to data from the World Bank, 2.01 billion tons of MSW are generated globally, and $33 \%$ is not adequately managed. The World Bank data show that MSW per capita generation is between $0.11-4.54 \mathrm{~kg} /$ day worldwide. Methods such as landfill, incineration for energy, and recycling come to the fore considering the most used MSW disposal schemes worldwide ${ }^{[1,15,16]}$. While $40 \%$ of worldwide MSW are managed by landfill, $13.5 \%$ by recycling, $11 \%$ by open area incineration, and $5.5 \%$ by composting, $30 \%$ of the MSW are still dumped in open areas ${ }^{[4]}$. All these show the importance of MSW management. There are many definitions of MSW management in the literature. MSW management comprehends the minimization of MSW at the source, processing, transport, disposal and monitoring, and control and inspection points in a manner that will result in the least harm to the environment. A waste management system's primary goal is to reduce waste at the source and ensure waste recovery with maximum recycling. The environment and human health are negatively affected due to the inadequacy of most waste management systems ${ }^{[17,18,19,20]}$.

The municipalities carried out solid waste management in Turkey in the framework of some laws such as 2872 Environmental Law Article-11, 5393 Municipalities Law Article-14 and 5216 Metropolitan Municipality Law Article-7 $7^{[17,21,22,23]}$.

The formation system methods used in MSW and na- tional waste management action plan, which is introduced for 2016-2023 and issued by the Ministry of Environment and Urbanization, must also be compatible ${ }^{[24]}$. In the first stage of the plan mentioned above, Turkey was separated into specific regions and became operational in MSW management associations. Each of these regions was determined to serve an area with a minimum effective radius of $30 \mathrm{~km}$ and a maximum effective radius of $65 \mathrm{~km}$. As a result, 116 waste unions in the country were established by dividing into three central regions and 11 sub-regions.

The objective of the present study is to (i) determine and evaluate MSW management by region, including amount and disposal methods, population served by MSW and MSW per capita, in Turkey between 2001-2018 (ii) reveal the relationship between population and MSW using simple linear regression technique.

\section{Material and Method}

We first examined the quantity and composition of MSW generated in Turkey; then analyzed the disposal methods, populations served by MSW, and MSW per capita.

Regarding data analysis, first, descriptive statistics were generated, then Pearson's correlation analysis was applied to determine the relationship between MSW generation and population. Finally, a simple linear regression technique was used to model the amount of solid waste by population. Ln and arcsin transformations were applied for data showing nonnormal distribution. $\mathrm{R}^{[25]}$ program was used for the analysis of the data. Maps on the amount of solid waste were created on the ArcGIS 10.2 program using the IDW (inverse distance weighted) method ${ }^{[26,27]}$.

Data and materials used in the study were obtained from the websites of the Turkish Statistical Institute (TUIK/TURKSTAT)) and the Directorate General of Environmental Impact Assessment, Permit, and Inspection of the Ministry of Environment and Urbanization. The research was limited to 2001-2018 as the solid waste data on the TURKSTAT website include only those years. In evaluating the relationship between the population and the amount of waste.

\subsection{Study Area}

Turkey, the transition point between Asia and Europe, is an upper-middle-income country, according to World Bank data for 2018, and is in the Developing Markets list, according to the UN World Economic Situation and Prospects Report ${ }^{[28,29]}$. The population of Turkey in 2019 was 83,154,997, according to the Address Based Population Registration System prepared by the Turkish Statistical 
Institute. As of 2019, there were 1390 municipalities in Turkey, including 30-metropolitan, 51-province, 519-metropolitan district, 403-local district, 387-town [30]. Seven geographic regions have been selected as the study area, namely: Marmara (Mrm), Central Anatolia (CA), Mediterranean (Med), Aegean (Aeg), Southeast Anatolia (SA), Black Sea (BS), and Eastern Anatolia (EA) regions.

\section{Results}

\subsection{MSW Situation in Turkey}

The average MSW in Turkey, the population served by MSW, MSW per capita per day between 2001 and 2018 are mapped in Figures 1-3.

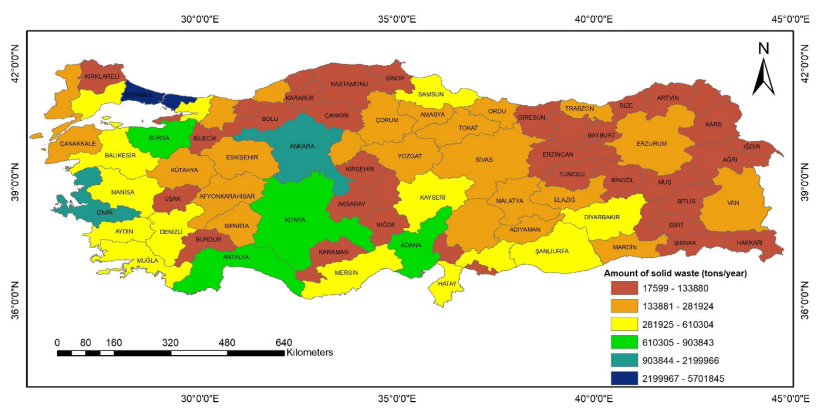

Figure 1. The average MSW in Turkey between 2001 and 2018

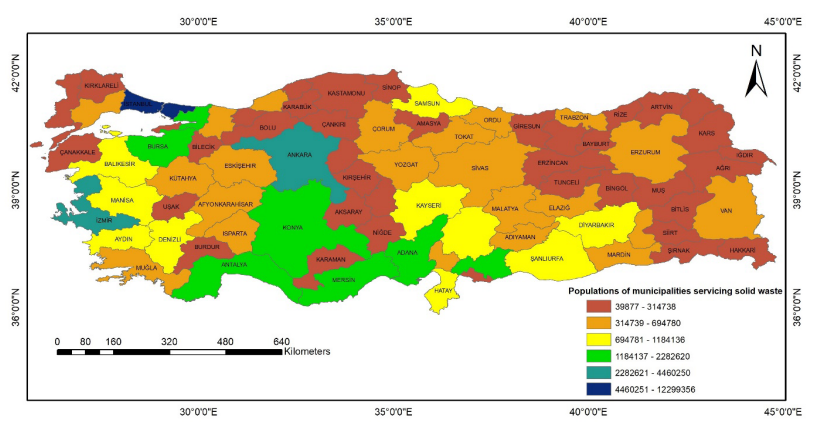

Figure 2. Average populations served by MSW between 2001 and 2018.

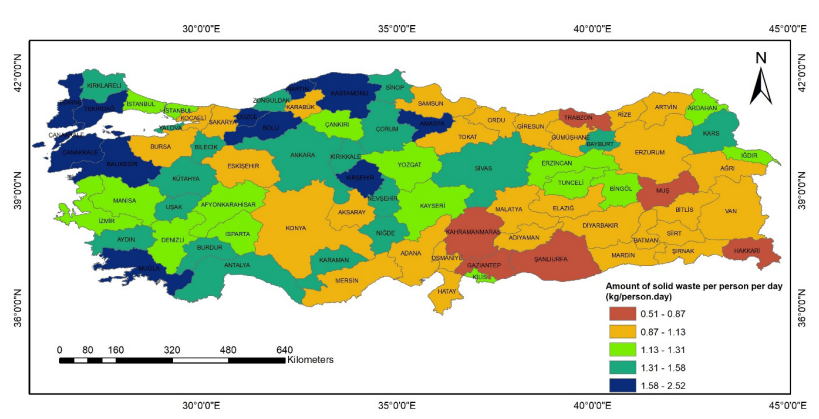

Figure 3. The average MSW per capita in Turkey between 2001 and 2018.
Table 1. MSW data by regions for 2001-2018.

\begin{tabular}{|c|c|c|c|c|}
\hline \multirow{2}{*}{ Regions } & \multicolumn{4}{|c|}{ Population served by MSW } \\
\hline & Min & Avearage & Max & 6 \\
\hline Mrm & 15411764 & 19425208 & 24642689 & 3576090.31 \\
\hline CA & 9237732 & 10500746 & 12344680 & 1075317.16 \\
\hline Med & 6833144 & 7956810 & 10096152 & 1235739.34 \\
\hline Aeg & 6933092 & 8072440 & 10044453 & 1174925.00 \\
\hline SA & 4417761 & 5719521 & 8091238 & 1348791.68 \\
\hline BS & 4523709 & 5080292 & 6029368 & 547554.32 \\
\hline EA & 3470719 & 3865888 & 4708001 & 470642.07 \\
\hline
\end{tabular}

Average MSW per capita (Kg / Person/day)

\begin{tabular}{|c|c|c|c|c|}
\hline & Min & Avearage & Max & 6 \\
\hline Mrm & 1.24 & 1.3827 & 1.58 & 0.12 \\
\hline CA & 1.07 & 1.3155 & 1.60 & 0.22 \\
\hline Med & 1.00 & 1.1555 & 1.33 & 0.12 \\
\hline Aeg & 1.23 & 1.4791 & 1.79 & 0.20 \\
\hline SA & 0.81 & 0.9809 & 1.17 & 0.10 \\
\hline BS & 1.14 & 1.2918 & 1.49 & 0.15 \\
\hline EA & 0.96 & 1.0782 & 1.19 & 0.08 \\
\hline
\end{tabular}

MSW Collected (MTon / Year)

\begin{tabular}{|c|c|c|c|c|}
\hline & Min & Average & Max & б \\
\hline Mrm & 7.37 & 8.92 & 11.22 & 1.26 \\
\hline CA & 4.21 & 4.86 & 5.40 & 0.41 \\
\hline Med & 2.82 & 3.33 & 4.22 & 0.39 \\
\hline Aeg & 3.50 & 4.00 & 4.84 & 0.44 \\
\hline SA & 1.28 & 1.94 & 2.89 & 0.56 \\
\hline BS & 1.86 & 2.21 & 2.39 & 0.18 \\
\hline EA & 1.21 & 1.49 & 1.86 & 0.22 \\
\hline
\end{tabular}

Analysis of the average MSW generation, as seen in Figure 1, Istanbul has the highest amount of solid waste due to its high population density. Ankara and İzmir are the other two provinces with very high solid waste deposits due to a very high population. Figure 2 shows 
Table 2. General characterization of MSW by region in Turkey (\%)

\begin{tabular}{|c|c|c|c|c|c|c|c|c|}
\hline Waste Component & Mrm & CA & Med & Aeg & SA & BS & EA & Turkey in general \\
\hline Organic & 51.98 & 53.47 & 56.19 & 48.02 & 50.54 & 54.81 & 54.73 & 52.30 \\
\hline Other & 14.86 & 28.48 & 16.68 & 19.98 & 23.87 & 14.52 & 18.42 & 18.85 \\
\hline Glass & 4.81 & 2.47 & 3.99 & 6.05 & 1.78 & 4.47 & 4.21 & 4.29 \\
\hline Plastic & 11.77 & 6.88 & 11.22 & 11.01 & 13.12 & 10.84 & 10.83 & 10.74 \\
\hline E-Waste & 0.19 & 0.08 & 0.24 & 0.16 & 0.00 & 0.32 & 0.03 & 0.16 \\
\hline Textile & 3.29 & 1.38 & 0.00 & 2.80 & 1.21 & 0.12 & 1.19 & 2.11 \\
\hline Ash & 0.36 & 0.84 & 0.77 & 0.80 & 2.69 & 3.15 & 1.64 & 0.89 \\
\hline Hazardous & 0.72 & 0.10 & 0.20 & 0.57 & 0.00 & 0.39 & 0.27 & 0.45 \\
\hline Paper - Cardboard & 10.35 & 5.11 & 8.95 & 8.36 & 5.11 & 8.68 & 7.67 & 8.48 \\
\hline Metal & 1.04 & 1.12 & 1.76 & 1.72 & 1.48 & 2.68 & 1.00 & 1.37 \\
\hline Packaging & 0.64 & 0.06 & 0.00 & 0.53 & 0.22 & 0.02 & 0.00 & 0.37 \\
\hline
\end{tabular}

the average populations served by MSW. Accordingly, Istanbul, Ankara, and Izmir can be listed as the provinces serving the highest number of people. According to the MSW generation per capita per day in Figure 3, Edirne, Tekirdağ, Çanakkale, Balıkesir, Muğla, Bolu, Düzce, Bartın, Kastamonu, Kırşehir and Amasya were the provinces generating the largest quantities of waste, whereas Kahramanmaraş, Trabzon, Gaziantep, Sanlıurfa, Muş and Hakkari generated the least quantities of MSW. The average MSW in Turkey is commonly estimated at 26.74 Mtons/year. MSW per capita in the country for 2018 was $1.16 \mathrm{~kg} /$ day. MSW generation, the population served by MSW, and MSW generation per capita per day are presented in Table 1.

Using the waste characterization in the status report (PESR) 2018, the approximate percentage of the overall waste characterization in Turkey's regions is shown in Table 2. Provincial solid waste characterization data were used to prepare Table 2. However, the waste characterization data for 25 provinces could not be obtained.

Table 2 showed that the rate of organic wastes generated in Turkey was the highest, followed by quantities of plastic and paper waste, and the rate of E-wastes was the lowest. The most generated waste types were in the following order by region; textile, hazardous, paper-cardboard and packaging in Marmara, organic in the Mediterranean, glass in Aegean, plastic in South East Anatolia, and E-waste, ash, and metal in the Black Sea, and the others in Central Anatolia.

\subsection{Analysis of Municipal Solid Waste Data by Region}

\subsubsection{Marmara}

Balıkesir, Bilecik, Bursa, Çanakkale, Edirne, İstanbul, Kırklareli, Kocaeli, Sakarya, Tekirdağ and Yalova are the provinces within the borders of this Region. Industry, trade, tourism, and agriculture are more developed than in the other regions. This part of the country also has clear lines regarding the ratio of urban to rural areas. It has the highest energy consumption, higher industrial production than the other regions combined, and the highest population density ${ }^{[30,31]}$. The region's area is $72666 \mathrm{~km}^{2}$, and the population density is estimated as 336.68 people $/ \mathrm{km}^{2}$. The MSW disposal methods used in the region between 20012018 are presented in Figure 4.

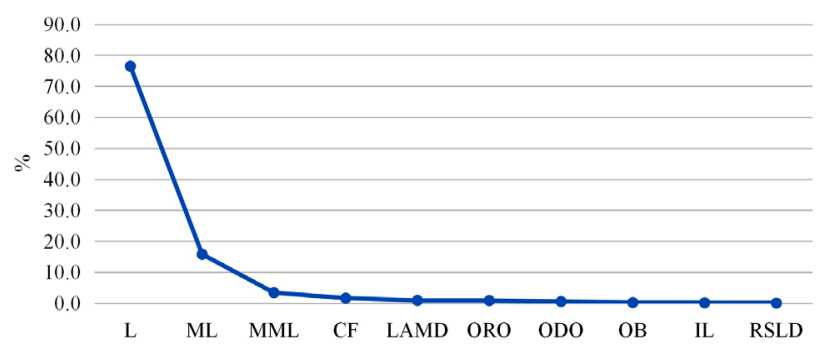

Figure 4. MSW disposal methods used in Marmara region.

MSW disposal methods used in Marmara were in the following order: landfills (L) (76.44\%), municipal landfills

DOI: https://doi.org/10.30564/re.v3i1.2895 
(ML) (15.8\%), metropolitan municipal landfills (MML) (3.41\%), compost facilities (CF) (1.64\%), and landfill in another municipal dump (LAMD) (0.91\%), other recovery operations (ORO) $(0.86 \%)$, other disposal operations (ODO) $(0.55 \%)$, and open burning (OB) $(0.21 \%)$; improper landfills (IL) $(0.14 \%)$, and dumping in river, stream and lake (RSLD) $(0.04 \%)$.

According to the PESR of the provinces in the Marmara Region, some district municipalities of Bilecik and Balikesir were still using the wild storage method in 2018. However, there were landfills in all the provinces ${ }^{[32]}$. According to the 2018's data, the population served by MSW was $19,425,208(98.4 \%)$ in the region. The highest and lowest population served by MSW was in Istanbul and Bilecik. The average MSW generation in the region was 8.92 Mtons/year, while the MSW generation per capita was 1.38 $\mathrm{kg} /$ day. Tekirdağ and Kocaeli had the highest and lowest MSW generation per capita, with $1.73 \mathrm{~kg} /$ day and 1.005 $\mathrm{kg} /$ day.

\subsubsection{Central Anatolia}

The population of the region, with an area of 136057 $\mathrm{km}^{2}$ which includes the provinces of Aksaray, Ankara, Çankırı, Eskişehir, Karaman, Kayseri, Kırıkkale, Kırşehir, Konya, Nevşehir, Niğde, Sivas, and Yozgat was $12,705,812$ with a density of 93.38 people $/ \mathrm{km}^{2}$ according to national census of 2019. The solid waste disposal methods in the region are given in Figure 5.

However, all provinces in the region have landfills, while some districts in Kırıkkale and Kırşehir used wild storage and on-site storage methods because of far from the landfill, some others sent their wastes to the landfill in Yozgat $^{[32]}$. The percentages of MSW disposed of by different methods were as follows: $33.79 \% \mathrm{ML}, 31.89 \% \mathrm{~L}$, $27.92 \%$ MML, 2.42\% ORO, 1.41\% LAMD, 1.39\% ODO, $0.41 \% \mathrm{IL}, 0.40 \% \mathrm{OB}, 0.37 \% \mathrm{RSLD}$, and $0 \% \mathrm{CF}$.

The highest and lowest MSW generation per capita was in Kırşehir with $1.66 \mathrm{~kg} /$ day and Eskişehir with $1.06 \mathrm{~kg} /$ day. The average MSW generation in the region was 4.86 Mtons/year with a minimum value of $0.06 \mathrm{Mtons} /$ year in Çankırı and a maximum value of 2.2 Mtons/year in Ankara. According to data from 2018, the population served by MSW was around 10,500,746 (94.1\%). The highest and lowest population served by MSW was Ankara and Çankırı.

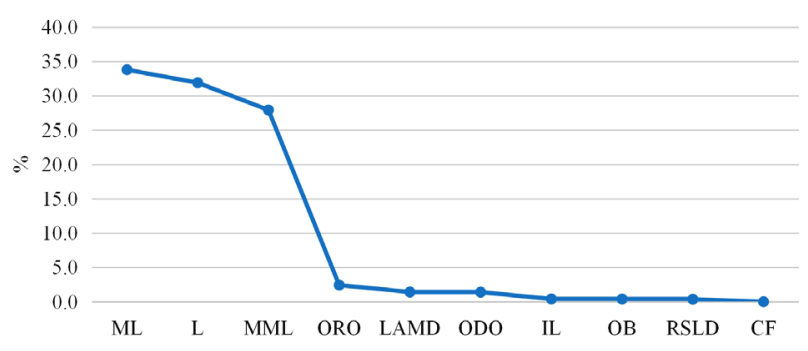

Figure 5. MSW disposal methods used in Central Anatolia region.

\subsubsection{The Mediterranean}

The population in the region, having an area of 89493 $\mathrm{km}^{2}$, which includes the provinces of Adana, Antalya, Burdur, Hatay, Isparta, Kahramanmaraş, Mersin, and Osmaniye, was $10,552,942$ with a density of 117.9 people/ $\mathrm{km}^{2}$ according to the national census of 2019 .

The percentage of MSW by disposal methods were as follows: $40.23 \% \mathrm{ML}, 37.86 \% \mathrm{~L}, 12.71 \% \mathrm{MML}, 3.09 \%$ LAMD, $1.40 \% \mathrm{CF}, 1.36 \%$ ODO, $1.02 \% \mathrm{IL}, 0.99 \%$ ORO, $0.79 \%$ OB, and $0.56 \%$ RSLD (Figure 6). $96.5 \%$ (7,956,810 people) of the region's population, the highest in Adana and lowest in Burdur, was served by MSW, according to data from 2018. The average MSW generation in the region was 3.33 Mtons/year, with a minimum in Burdur and a maximum in Antalya.

The highest and lowest MSW generation per capita was in Antalya with $1.66 \mathrm{~kg} /$ day and Kahramanmaraş with $0.86 \mathrm{~kg} /$ day, while the average was $1.6 \mathrm{~kg} /$ day. The municipalities in the region recycled about 100,817 tons/year of MSW. According to the regional 2018 PESR, 90\% of the domestic wastes in Adana were disposed of with regular storage. The number of landfill facilities in Antalya, Hatay, and Mersin was five, two, and two, respectively. The Kahramanmaraş province disposed of solid waste in landfills (for 11-district) and wild storage (for 4-district). There was one sanitary landfill in each remaining province $^{[32]}$.

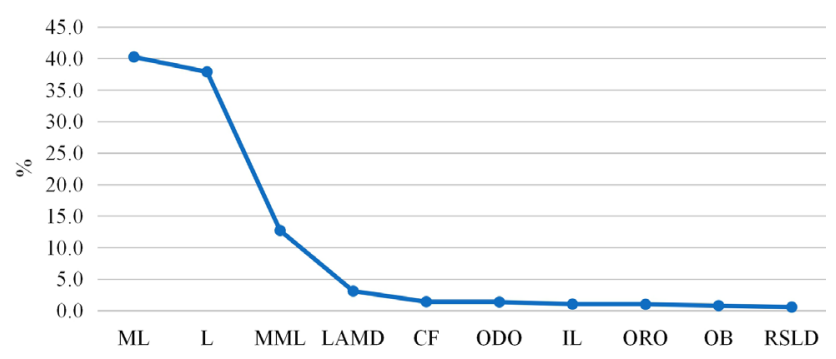

Figure 6. MSW disposal methods used in in the Mediterranean region. 


\subsubsection{Aegean}

There are eight provinces in the Aegean region, namely Afyonkarahisar, Aydın, Denizli, Izmir, Kütahya, Manisa, Muğla, and Uşak. The population of the region with an area of $90,251 \mathrm{~km}^{2}$ was $10,318,157$, according to the national census of 2019. Its population density was 114.3 persons $/ \mathrm{km}^{2}$.

The percentage of MSW by disposal methods were as follows: 36.3\% L, 28.5\% ML, 19.4\% MML, 5.5\% ORO, $3.7 \%$ CF, 2.4\% LAMD, 1.3\% ODO, 1.2\% IL, 0.7\% OB, and $0.5 \%$ RSLD (Figure 7 ). The average population served by MSW in the region was 1,009,055 (95.5\%), with the highest in İzmir and the lowest in Uşak. The highest and lowest MSW generation per capita was in Muğla with $2.50 \mathrm{~kg} /$ day and Denizli with $1.16 \mathrm{~kg} /$ day, while the average was $1.48 \mathrm{~kg} /$ day. The highest and lowest MSW generation was in Muğla, and Kütahya, and Uşak in the given period. While the regional average of MSW generation was 4.0 Mtons/year, the region's municipalities recycled about 43703 tons/year of that amount. According to the regional 2018 PESR, there were a total of 14 landfill sites: three in Aydın, one in Uşak, four in Muğla, two in İzmir and Denizli, and one each in Afyonkarahisar and Manisa. However, wild storage methods were also in use in some districts of Aydın and Uşak.

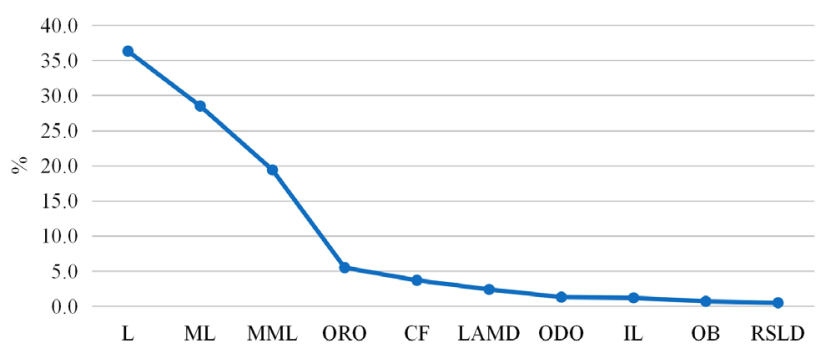

Figure 7. MSW disposal methods used in the Aegean region

\subsubsection{Southeastern Anatolia}

The Southeastern Anatolia Region, with an area of $59,176 \mathrm{~km}^{2}$, including Adiyaman, Batman, Diyarbakır, Gaziantep, Kilis, Mardin, Siirt, Şanlıurfa, and Şırnak provinces, had the population of $8,876,531$ with 150 people $/ \mathrm{km}^{2}$ population density.

The percentage of MSW by disposal methods were as follows: 50.92\% L, 26.74\% MML, 9.56\% ML, 4.61\% ODO, 2.89\% OB, 2.0\% RSLD, 1.43\% IL, 1.27\% ORO, $0.59 \%$ LAMD, $0 \%$ CF (Figure 8 ). The average population served by MSW in the region was 635,502 (91,4\%), with the highest in Gaziantep and lowest in Kilis. The highest and lowest MSW generation per capita was in Muğla with $1.16 \mathrm{~kg}$ /day and Denizli with $0.82 \mathrm{~kg} /$ day, while the aver- age was $0.98 \mathrm{~kg} /$ day. The highest and lowest solid waste generated was in Gaziantep and Kilis in the given period. While the regional average of MSW generation was 1.94 Mtons/year. According to the PESR published in 2018, there were no landfills in Diyarbakır, Şırnak, and Batman provinces, and the wild storage disposal method was still in use. However, Gaziantep had two landfills and, other provinces, including Kilis, Mardin, Siirt, and Şanlıurfa, had one each.

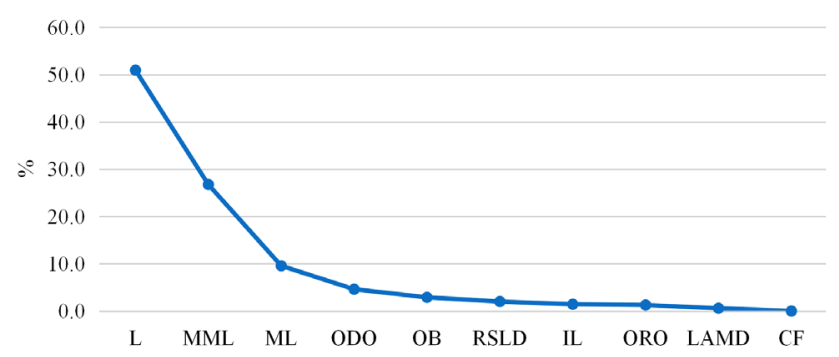

Figure 8. MSW disposal methods used in the Southeast Anatolia region.

\subsubsection{The Black Sea}

The provinces in the region are Amasya, Artvin, Bartin, Bayburt, Bolu, Çorum, Düzce, Giresun, Gümüşhane, Karabük, Kastamonu, Ordu, Rize, Samsun, Sinop, Tokat, Trabzon and Zonguldak. The region with an area of $116169 \mathrm{~km}^{2}$, had the population and population density of $7,674,496$ and 66.06 people $/ \mathrm{km}^{2}$, according to national census in 2019.

The percentage of MSW by disposal methods were as follows: $52.35 \% \mathrm{ML}, 31.74 \% \mathrm{~L}, 6.25 \% \mathrm{MML}, 3.44 \%$ ODO, 2.73\% LAMD, 2.13\% IL, 0.54\% RSLD, 0.47\% OB, $0.35 \%$ ORO, 0\% CF (Figure 9). The average MSW generation in the Black Sea region was 2.21 Mton / year, with the highest in Samsun and lowest in Bayburt. The municipalities in the region recycled 9089 tons/year of MSW. The highest and lowest MSW generation per capita was in Kastamonu with $1.69 \mathrm{~kg} /$ day and Trabzon with 0.79 $\mathrm{kg} /$ day, while the average was $1.29 \mathrm{~kg} /$ day. The average population served by MSW was about 5,080,292 (75.5\%), with the highest in Samsun and the lowest in Bayburt. According to PESR report, the MSW disposal methods vary by province and some were as follows: wild dump in Karabük, Amasya, Bartın, Giresun, regular storage in Amasya, Artvin, Samsun, Tokat, Bayburt, Bolu, Çorum, Düzce, Kastamonu, Zonguldak, and Sinop, and waste transfer in Gümüşhane. While constructing a sanitary landfill was still ongoing in Ordu, Rize and Trabzon jointly used the landfill method. 


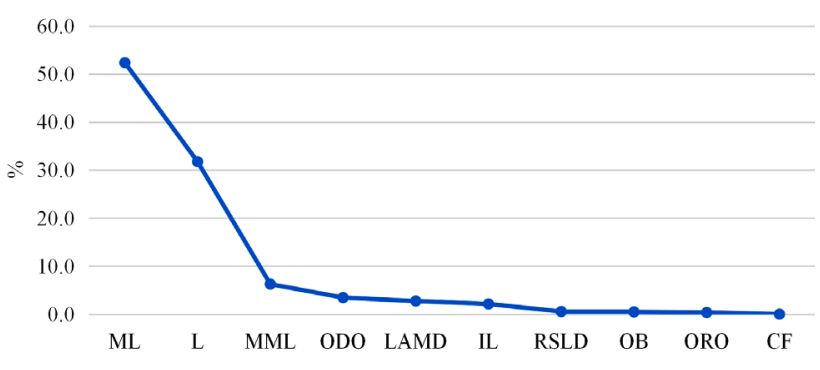

Figure 9. MSW disposal methods used in the Black Sea region.

\subsubsection{Eastern Anatolia}

Eastern Anatolia Region, whose population was 5,966,101 in 2019 with 39,7 people/ $\mathrm{km}^{2}$, consists of Ağr1,

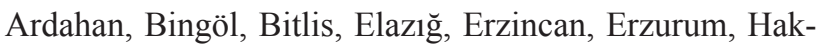
kari, Iğdır, Kars, Malatya, Muş, Tunceli and Van provinces. The area of the region is $150,210 \mathrm{~km}^{2}$.

The percentage of solid waste by disposal methods were as follows: $57.75 \% \mathrm{ML}, 23.57 \% \mathrm{~L}, 12.49 \% \mathrm{MML}$, $1.62 \% \mathrm{IL}, 1.05 \%$ LAMD, $1.05 \%$ RSLD, $0.89 \%$ ODO, $0.86 \%$ OB, $0.72 \%$ ORO, and $0 \%$ CF (Figure 10 ). The average MSW generation in the region was approximately 1.49 Mtons/year, with the lowest in Ardahan and highest in Van. The highest and lowest MSW generation per capita was in Kars with $1.45 \mathrm{~kg} /$ day and Hakkari with 0.51 $\mathrm{kg} /$ day, while the average was $1.08 \mathrm{~kg} /$ day. The average population served by MSW was $3,865,888$ (77.6\%), with the highest in Van and the lowest in Ardahan. The 2018 PESR report showed that different disposal methods vary with provinces as follows; sanitary landfill in Bingöl, Erzurum, and Iğdır, regular landfills in Malatya, Bitlis, Erzincan, and Elazı $\breve{g}$, wild dump in Hakkari, Ardahan, Kars, Malatya, Bitlis, Erzincan, and Elazı̆g. The construction of landfills was ongoing in Tunceli and Van.

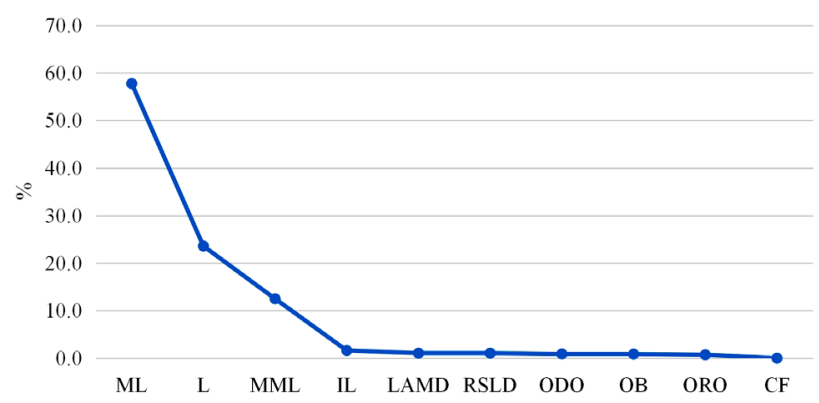

Figure 10. MSW disposal methods used in the Eastern Anatolia region.

\subsection{Relationship between Population and MSW}

Pearson's correlation analysis was used to determine the relationship between MSW and population, and simple linear regression analysis was used to model this rela- tionship. Statistical analyses were carried out using the $\mathrm{R}$ program. The Pearson correlation coefficients ( $\mathrm{r}$ ) between population and solid waste varied between years and ranged from 0.92 to 0.98 (Figure 11).

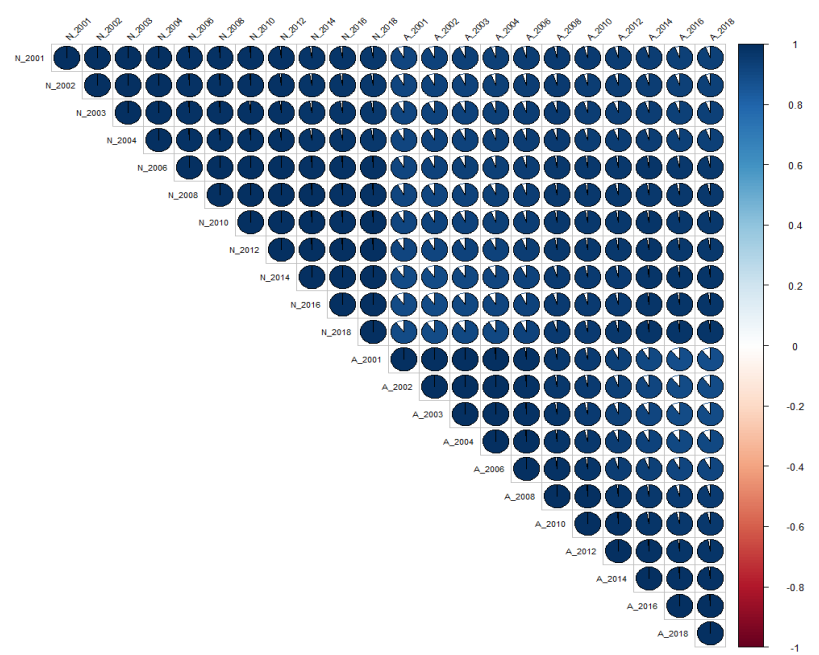

Figure 11. Correlation diagram between population $(\mathrm{N})$ and the MSW generation (A) (the change of color from light to dark and the closing of the cake slice gap show that the relationship is significant)

The adjusted coefficient of determination $\left(\mathrm{R}_{\text {adj }}^{2}\right)$ varied by year and ranged from 0.84 to 0.95 (Figure 12). That means $84 \%$ and $95 \%$ of the solid waste variation could be explained using the population as the independent variable. On the other hand, the $\mathrm{r}$ and $\mathrm{R}_{\text {adj }}^{2}$ were determined as 0.97 and 0.95 without taking years into account (Figure 13).

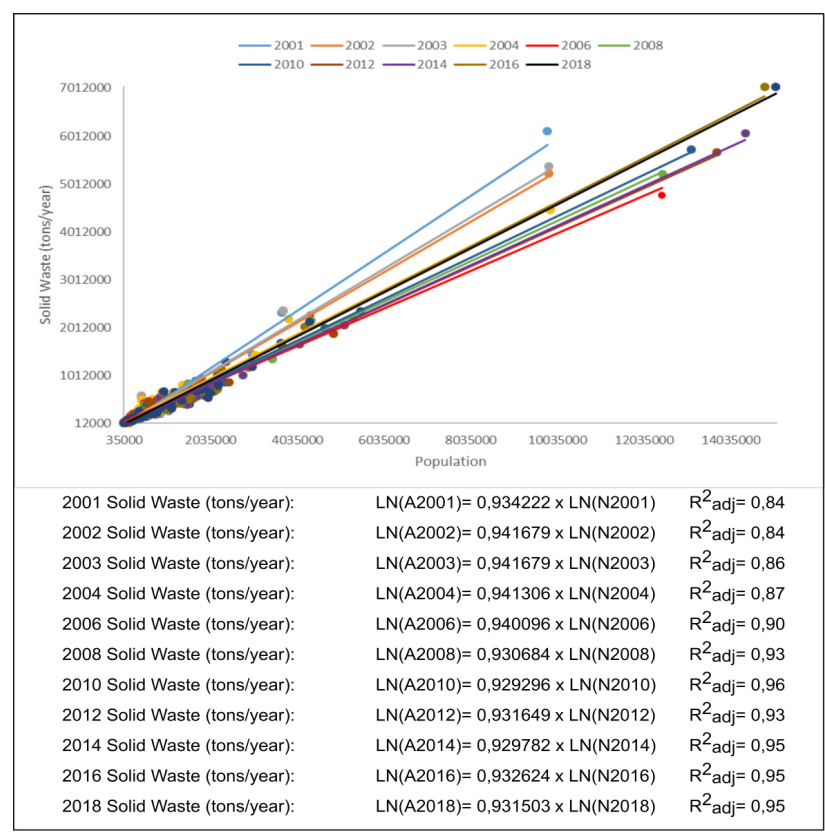

Figure 12. The relationship between the MSW generation in Turkey and population by year modeled using simple regression 


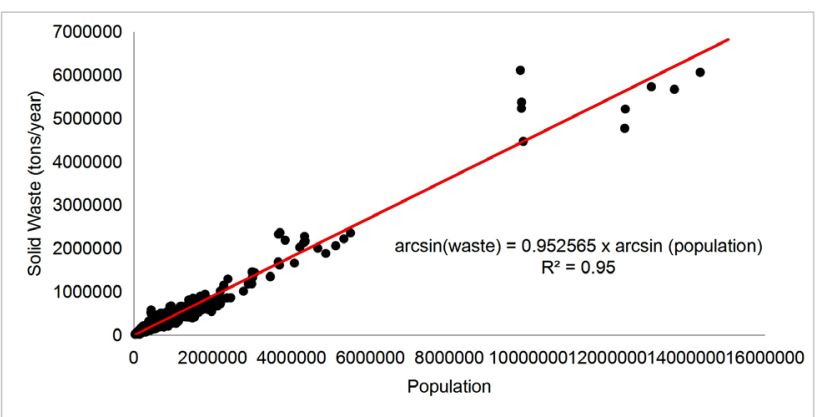

Figure 13. Relationship between the total population and the MSW generation modeled using simple regression

\section{Discussion}

This study related solid waste to population, besides the amount and disposal methods of municipal solid waste (MSW), frequently studied in Turkey.

Municipalities' population served by solid waste in the country increased in the following order by region: Marmara (98.4\%) > Mediterranean (96.5\%) > Aegean (95.5) $>$ Central Anatolia (94.1\%) > South East Anatolia (91.4\%) $>$ Eastern Anatolia (77.6\%) > Black Sea (75.5). This order could be attributed to share of average regional GDP, which was the highest in Marmara ${ }^{[33]}$. This is because the higher the GDP, the higher the population served by solid waste. UNSD ${ }^{[34]}$ reported the lowest population served by municipal waste collection with lower than $30 \%$ in some countries such as Burkina Faso, Madagascar and Yemen, Zambia, Senegal and Guatemala, having relatively lower GDP and development level.

The average MSW generation per capita in Turkey was $1.24 \mathrm{~kg} /$ day. MSW generation per capita was the highest in Aegean with $1.48 \mathrm{~kg} /$ day and the lowest in Southeastern Anatolia with $0.98 \mathrm{~kg} /$ day. The highest MSW generation per capita in Aegean could be attributed to increased population in especially tourism season ${ }^{[35]}$ in addition to relatively higher GDP. Ramaswamy and Kumar ${ }^{[36]}$, for example, reported an increase of about $1 \mathrm{~kg}$ /day per capita due to coming tourists also causing some environmental problems. On the other hand, the lowest MSW generation per capita could be related to the lowest GDP in the country. GDP is globally known as an indicator of MSW generation per capita, despite not strong correlations between them. While MSW generation per capita in EU countries ranged from 0,85 to $2.13 \mathrm{~kg} /$ day, it ranged 0.16 to $1.78 \mathrm{~kg} /$ day in Middle East and North Africa, having lower GDP than EU ${ }^{[37]}$. Another study in Tehran ${ }^{[38]}$ reported correlation coefficient between GDP and MSW generation per capita to be 0.91 . Similar results were also found by some researchers ${ }^{[39,40,41]}$.
MSW disposal techniques in Turkey vary from landfills including L, ML, MML, LAMD and, IL to ORO, CF, OB, and RSLD. Landfill, the most-used MSW disposal method in Turkey, ranged from 87.8 to $96.7 \%$ by regions (Figure 4-10). It is also the globally most-used one with $71 \%{ }^{[42]}$, especially in developing countries such as Turkey, India, and China due to inadequacies in economic, technology, skilled and educated people, and available land ${ }^{[43]}$. For example, while China disposes of $96.9 \%$ of its MSW with landfill followed by incineration $(1.8 \%)$ and composting $(1.3 \%)^{[44]}$, India disposes of 80 to $90 \%$ of its MSW with this method ${ }^{[45]}$. Tehran, on the other hand, dispose of $76 \%$ of its MSW.

The relationship between the municipal population and MSW was also investigated. The adjusted coefficient of determination $\left(\mathrm{R}_{\text {adj }}^{2}\right)$ varied by year and ranged from 0.84 to 0.95 (Figure 12). That means $84 \%$ and $95 \%$ of the solid waste variation could be explained using the population as the independent variable. On the other hand, the $r$ and $\mathrm{R}_{\text {adj }}^{2}$ were determined as 0.97 and 0.95 without taking years into account (Figure 13). Dyson and Chang ${ }^{[47]}$ examined the relationship between solid waste produced in America, population, and income. They found $\mathrm{R}_{\text {adj }}^{2}$ ranged between 0.89 and 0.99. Bandara et al. ${ }^{[47]}$, in Sri Lanka, estimated the amount of organic waste produced per capita by various income groups using the linear regression model. The model included the number of people in a household in the lower- and middle-income groups and the number of working people in the upper-income group as independent variables. Mateu-Sibert et al. ${ }^{[48]}$, in their study carried out in Spain, found that a $1 \%$ increase in the tourist population increased the amount of municipal solid waste by $0.3 \%$.

\section{Conclusions}

The study showed that most-used MSW disposal method in Turkey is landfill in a rate of $87.8-96.7 \%$, which is a traditional waste disposal method, mostly-used in developing countries such as China and India, are used as of 2018. Use of other disposal methods is limited to the rate of 0.72 to 1.93 , including burning, composting and other recovery techniques. The study also showed that the population served by MSW were the rate of 75.5 to $98.4 \%$, with an average of $89.9 \%$. This rate is little bit higher than world average (about $81.5 \%$ as of 2011).

This disposal method could result in some environmental problems such as odor, visual pollution and, greenhouse gases emitting into the atmosphere. Taking the adverse outcome of this method into account, it is seen that more appropriate and efficient management systems are required. For example, to cope with greenhouse gas

DOI: https://doi.org/10.30564/re.v3i1.2895 
emissions from landfill areas, causing global warming and indirect adverse impact on human health, should be converted into cleaner energy together with some techniques such as waste-to-energy technology, sanitary landfill with energy recovery system, and MSW sorting plant.

Therefore, recycling systems should be planned in all provinces and raise awareness of the public for zero waste strategy. Also, provided that the abovementioned strategies are implemented, they will be more appropriate in terms of environment and economics. Therefore, waste recycling should be encouraged, with the support of citizens and non-governmental organizations.

The results and equations from the present study could be used to estimate MSW to be generated in the regions, especially in waste management plans.

\section{References}

[1] Das, S. Lee, S. H., Kumar, P., Kim, K. H., Lee, S. S., Bhattacharya, S.S. Solid waste management: Scope and the challenge of sustainability, J. Clean. Prod., 2019, 228: 658-678.

[2] Bach, Q.V., Chen,W.H., Eng,C.F., Wang, C.W., Liang,K.C., Kuo, J.Y. Pyrolysis characteristics and non-isothermal torrefaction kinetics of industrial solid wastes, Fuel, 2019, 251: 118-125.

[3] Wang, H., Wang, C., Municipal solid waste management in Beijing: Characteristics and challenges, Waste Manag. Res., 2013, 31(1): 67-72.

[4] Kaza, S., Yao, L., Bhada-Tata, P., Woerden, F. V., What a Waste 2.0 A Global Snapshot of Solid Waste Management to 2050, International Bank for Reconstruction and Development / The World Bank, 2018.

[5] Gündüz Yılmaz A., Türkiye'de yoksullukla mücadele üzerine bir inceleme, Elektronik Sosyal Bilimler Dergisi, 2006, 5(15): 34-55.

[6] Chen, Y.C., Effects of urbanization on municipal solid waste composition, Waste Manag., 2018, 79: 828-836.

[7] Pereira, T.S., Fernandino, G., Evaluation of solid waste management sustainability of a coastal municipality from northeastern Brazil, Ocean Coast. Manag., 2019, 179: 104839.

[8] Kolekar, K.A., Hazra, T., Chakrabarty, S.N., A Review on Prediction of Municipal Solid Waste Generation Models, Procedia Environ. Sci., 2016, 35: 238244.

[9] Ozcan, H.K., Guvenc, S.Y., Guvenc, L., Demir, G., Municipal solid waste characterization according to different income levels: A case study, Sustain., 2016, 8: 10 .

[10] Turan, N.G., Çoruh, S., Akdemir, A., Ergun, ON, Municipal solid waste management strategies in Tur- key, Waste Manag., 2009, 29(1): 465-469.

[11] Jung, H., Sewu, D.D., Ohemeng-Boahen, G., Lee, D.S., Woo, S.H., Characterization and adsorption performance evaluation of waste char by-product from industrial gasification of solid refuse fuel from municipal solid waste, waste Manag., 2019, 91:pp. 33-41.

[12] Marques, R.C., Simões, P., Incentive regulation and performance measurement of the Portuguese solid waste management services, Waste Manag. Res., 2009, 27(2):188-196.

[13] Mesjasz-Lech, A., Reverse logistics of municipal solid waste - Towards zero waste cities, Transp. Res. Procedia, 2019, 39 (2018): 320-332.

[14] Yılmaz, İ.H., Abdulvahitoğlu, A., Evaluation of municipal solid waste options in Turkey: Scenarios for energy recovery, carbon mitigation and consequent financial strategies, Resour. Conserv. Recycl., 2019, 147 (February):95-110.

[15] Trends in Solid Waste Management, https://datatopics.worldbank.org/what-a-waste/trends_in_solid_ waste_management.html. [Accessed: 15.11.2019]

[16] Gu, T., Yin, C., Ma, W., Chen, G., Municipal solid waste incineration in a packed bed: A comprehensive modeling study with experimental validation, Appl. Energy, 2019, 247(March):127-139.

[17] Güleç Solak, S., Pekküçükşen, Ş., Municipal solid waste management in Turkey: A comparative analysis, MANAS Journal of Social Studies, 2018, 7(3): 653-683.

[18] Demirarslan, K.O., Başak, S., "Solid waste management in Eastern Black Sea Region Provinces, Ulus. Çevre Bilim. Araştırma Derg., 2018, 1(3): 117-132.

[19] Evin, H., Demiral, B., Solid Waste Management in Malatya: Effects on Local Environmental Policies of Urbanization, Social Sciences Research Journal, 2018, 7(2): 277-295.

[20] Gülmez, M., Municipal solid waste management at local level -derince example, Master Thesis, 2016, T.C. Gebze Technical University Graduate School of Natural and Applied Science, Turkey.

[21] Demirarslan, O., Demirarslan, D., Development of New Settlement Areas and Solid Waste Problem in Cities: Case Study on Izmit - Yahyakaptan Neighbourhood, Journal of Natural Hazards and Environment, 2016, 2(2): 108-120.

[22] Bay, M., Waste management and policies in municipalities: Karaman example, The Journal of International Social Research, 2018, 11(61): 669-781.

[23] Zengin, E., Ulutaş, K., Determination and Applyingof Municipal Solid Waste Fees in Metropolitan District Municipality, Yalova Üniversitesi Sos. Bilim. 
Derg., 2016, 6(11): 26-26.

[24] Korucu, M.K., A criticism of method selection approach which is used in the national waste management action plans for management of municipal solid wastes, Ulus. Çevre Bilim. Araştırma Derg., 2019, 2(4): 169-176.

[25] Team, R. C. 2013. R: A language and environment for statistical computing. URL http://www.R-project. org/. [Accessed: 10.01. 2020]

[26] Childs, C. 2004. Interpolating surfaces in ArcGIS spatial analyst. ArcUser, July-September, 3235, 569

[27] ESRI, E. 2014. ArcMap 10.2. Redlands, USA.

[28] Data for Turkey, The World Bank, https://data. worldbank.org/?locations=TR-XT. [Accessed: 09.09. 2020]

[29] United Nations, World economic situation prospects, https://www.un.org/development/desa/dpad/wp-content/uploads/sites/45/WESP2019_BOOK-ANNEXen.pdf [Accessed: 09.02.2020]

[30] https://www.e-icisleri.gov.tr/Anasayfa/MulkiIdariBolumleri.aspx. [Accessed: 09.02.2020]

[31] Kiliç, A., Kum, S., Ünal, A., Kindap, T., Air pollution modeling, pollution reduction and exposure analysis in Marmara Region, Balıkesir Üniversitesi Fen Bilim. Enstitüsü Derg., 2014, 16(1): 27-46.

[32] Provincial Environmental Status Reports (PESR), 2012-2018, Directorate General of Environmental Impact Assessment, Permit and Inspection, Republic of Turkey Ministry of Environment and Urbanisation, https://ced.csb.gov.tr/il-cevre-durum-raporlari-i-82671. [Accessed: 09.02.2020]

[33] TUIK, 2021, https://data.tuik.gov.tr/ (Access: 19.03.2021).

[34] UNSD, Municipal Waste collection Data, United Nations Statistical Division,. 2011, https://unstats.un.org/unsd/environment/municipalwaste.htm (accessed date:22.03.202).

[35] Ezeah C., Fazakerley J., Byrne T. Tourism Waste Management in the European Union: Lessons Learned from Four Popular EU Tourist Destinations, American Journal of Climate Change, 2015, 4, 431445.

[36] Ramaswamy, S. and Sathis Kumar, Ganasen, Tourism and Environment: Pave the Way for Sustainable Eco-Tourism (March 5, 2010). Available at SSRN: https://ssrn.com/abstract=1565366 or http://dx.doi. org/10.2139/ssrn.1565366.

[37] Kawai, K., \& Tasaki, T. Revisiting estimates of municipal solid waste generation per capita and their reliability. Journal of Material Cycles and Waste Management, 2016, 18(1), 1-13.

[38] Majlessi, M., Zamanzadeh, M., Alavi, N., Amanidaz,
N., \& Bakhshoodeh, R. Generation rates and current management of municipal, construction and demolition wastes in Tehran. Journal of material cycles and waste management, 2019, 21(1), 191-200.

[39] Mazzanti, M., Zoboli, R. Municipal Waste Kuznets Curves: Evidence on Socio-Economic Drivers and Policy Effectiveness from the EU. Environ Resource Econ, 2009, 44, 203-230.

[40] Liu C., Wu X. Factors influencing municipal solid waste generation in China: A multiple statistical analysis study, Waste Management \& Research, 2010, 29(4), 371-378.

[41] Alajmi, R.G. The Relationship between Economic Growth and Municipal Solid Waste \& Testing the EKC Hypothesis: Analysis for Saudi Arabia, Journal of International Business Research and Marketing, 2016, 1(5), 20-25

[42] Abdel-Shafy, H. I., \& Mansour, M. S. Solid waste issue: Sources, composition, disposal, recycling, and valorization. Egyptian journal of petroleum, 2018, 27(4), 1275-1290.

[43] Al-Ghouti, M. A., Khan, M., Nasser, M. S., Al Saad, K., \& Heng, O. E. Recent advances and applications of municipal solid wastes bottom and fly ashes: Insights into sustainable management and conservation of resources. Environmental Technology \& Innovation, 2020. 101267.

[44] Zheng, S., Liu, W., Zhi, Q. Cleaner waste management: a review based on the aspects of technology, market and policy. Energy Procedia, 2016, 104, 492497.

[45] Kumar, A., \& Agrawal, A. Recent trends in solid waste management status, challenges, and potential for the future Indian cities-A review. Current Research in Environmental Sustainability, 2020, 2, 100011

[46] Dyson, B., Bin Chang, N., Forecasting municipal solid waste generation in a fast-growing urban region with system dynamics modeling, Waste Manag., 2005, 25(7): 669-679.

[47] Bandara, NJGJ, Hettiaratchi, J.P.A., Wirasinghe, S.C., Pilapiiya, S., Relation of waste generation and composition to socio-economic factors: A case study, Environ. Monit. Assess., 2007, 135(1-3): 31-39.

[48] Mateu-Sbert, J., Ricci-Cabello, I., Villalonga-Olives, E., Cabeza-Irigoyen, E., The impact of tourism on municipal solid waste generation: The case of Menorca Island (Spain), Waste Manag., 2013, 33(12):2589-2593. 